Marek Krynke ${ }^{1}$

\title{
ANALIZA NUMERYCZNA OBCIĄŻENIA ŚRUB W ŁOŻYSKU WIEŃCOWYM
}

\begin{abstract}
Streszczenie: W niniejszym rozdziale dokonano analizy połączenia śrubowego mocującego łożysko wieńcowe do różnych struktur jego zabudowy. Korzystając z metody elementów skończonych zbadano wpływ podatności podzespołów wsporczych na rozkład sił przypadających na poszczególne śruby mocujące łożysko. Określono wartości obciążenia śrub i ich rozkład po obwodzie łączonych pierścieni łożyska.
\end{abstract}

Słowa kluczowe: łożyska wieńcowe, połączenia śrubowe, nośność łożysk.

\section{Wprowadzenie}

W budowie maszyn roboczych ciężkich do posadowienia nadwozia wykonującego ruch obrotowy na podwoziu stosuje się wielkogabarytowe łożyska toczne zwane łożyskami wieńcowymi. Łożyska te są łączone z siedziskami maszyny roboczej za pomocą wstępnie napiętych połączeń śrubowych. Śruby mocujące pierścienie łożysk wieńcowych do konstrukcji wsporczych są ważnym fragmentem całego mechanizmu obrotu, wpływają one w dużym stopniu na sztywność pierścieni łożyskowych, jednocześnie wytrzymałość śrub często decyduje o obciążalności całego układu roboczego.

Podstawowym kryterium obliczania śrub jest ich wytrzymałość umożliwiająca przeniesienie obciążenia zewnętrznego łożyska. Stosuje się w tym celu śruby $\mathrm{z}$ napięciem wstępnym, warunkiem poprawności połączenia jest zachowanie kontaktu między łączonymi powierzchniami pierścieni łożyska i zabudowy. Warunki te może spełnić wiele rozwiązań połączenia z większą lub mniejszą liczbą śrub o określonej średnicy.

${ }^{1}$ dr inż., Politechnika Częstochowska, Wydział Zarządzania, Instytut Inżynierii Produkcji, e-mail: krynke@zim.pcz.pl 
Dostępne w literaturze metody służące do wyznaczenia nośności łożysk wieńcowych najczęściej nie uwzględniają wpływu podatności podzespołów wsporczych oraz podatności śrub mocujących łożysko (DZIURSKi A., KANia L., MAZANEK E. 2002, MAZANEK E., KRYNKe M. 2010). Uwzględnienie tych czynników możliwe jest tylko przy zastosowaniu metod numerycznych. Jednak samo stosowanie tych metod wprowadza już pewien błąd obliczeń, a dodatkowo autorzy prac wykorzystujących je do wyznaczenia rozkładu obciążenia wewnętrznego $\mathrm{w}$ łożysku nie są $\mathrm{w}$ stanie uwzględnić wszystkich parametrów konstrukcyjnych, co wprowadza dodatkowe błędy. Jednym z ważnych parametrów często pomijanych przy modelowaniu konstrukcji wsporczych łożysk wieńcowych są połączenia śrubowe. Główną przyczynę awarii połączeń śrubowych w czasie eksploatacji łożysk wieńcowych, poza materiałem, upatruje się w niedostatecznej sztywności elementów nośnych oraz w znacznej deplanacji powierzchni stykowych kołnierzy. W wielu bowiem urządzeniach ze względu na ograniczenie wysokości węzła obrotowego nie udaje się skonstruować dostatecznie sztywnych ram o nie zmieniających się skokowo sztywnościach, co jest przyczyna występowania rozkładów sił w łożyskach znacznie odbiegających od zakładanych. Potwierdza to szereg badań eksperymentalnych i symulacyjnych przedstawionych w pracach (KANIA L., ŚPIEWAK S. 2014, Kania L., KRYnKe M., MAZANeK E. 2012, SMOLNICKI T. 2013).

W niniejszym rozdziale zaprezentowano i porównano ze sobą rozkłady sił w poszczególnych śrubach mocujących łożysko wieńcowe, które zabudowano $\mathrm{w}$ różnych podzespołach wsporczych (rys. 2.1). Wskazano punkty nadmiernego obciążenia przenoszonego przez łożysko, które pracuje $\mathrm{w}$ podzespołach wsporczych nie zapewniających odpowiedniej ostoi dla łożyska wieńcowego.

$\mathrm{Z}$ uwagi na to, że łożyska wieńcowe montowane w maszynach roboczych są projektowane na granicy dopuszczalnych stanów obciążenia elementów łożyska, dokładne obliczenie nośności łożyska wieńcowego jest sprawą bardzo ważną. Należy tu mieć na uwadze fakt, że w wielu 
urządzeniach uszkodzenie, czy zniszczenie łożyska wieńcowego wymaga wyłączenia urządzenia $z$ eksploatacji na długi czas i generuje wysokie koszty naprawy.

\section{Podzespól wsporczy i lożysko wieńcowe}

Istnieje wiele rozwiązań konstrukcyjnych podzespołów wsporczych, które charakteryzują się zróżnicowaną budową, kształtowaną indywidualnie ze względu na przenoszone obciążenia, rodzaj zabudowy itp. W niniejszej analizie skupiono się na trzech różnych podzespołach wsporczych (rys. 2.1). Przedstawione konstrukcje wsporcze różnią się między sobą sposobem osadzenia łożyska wieńcowego. Pierwszy i drugi podzespół wsporczy składa się z płyty osadzonej na podłużnicach wykonanych $\mathrm{z}$ zespawanych ze sobą blach, tworzących zamknięte przekroje skrzynkowe (rys. 2.1a,b). W podzespole trzecim zamiast płyty zastosowano dźwigar pierścieniowy $\mathrm{w}$ postaci grubościennej tulei z kołnierzem do mocowania łożyska. Wszystkie trzy rodzaje konstrukcji dolnej ramy nośnej posiadają dwie płaszczyzny symetrii.

a)

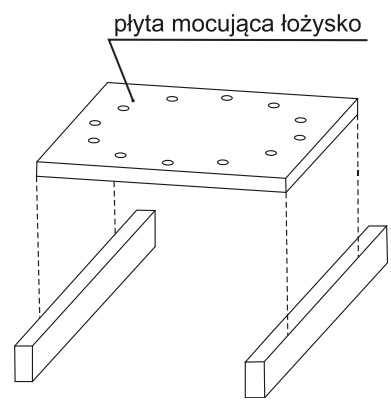

b)

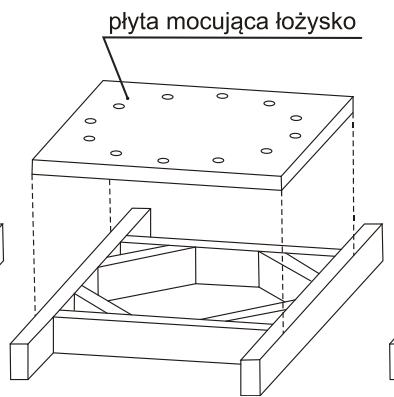

c)

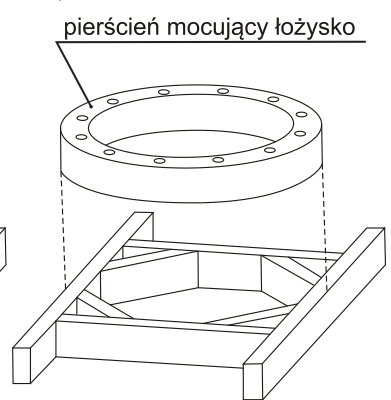

Rys. 1. Trzy rodzaje postaci podzespolów wsporczych przyjęte do analizy oznaczone jako model V1 (a), model V2 (b), model V3 (c).

Źródło: opracowanie na podstawie (SMOLNICKI T. 2013) 
Do obliczeń przyjęto katalogowe łożysko wieńcowe kulkowe jednorzędowe o styku czteropunktowym (rys. 2) (ROTHER ERDE 2008). W łożysku takim występuje jeden rząd kulek przy czym każda kulka współpracuje $\mathrm{z}$ dwoma parami bieżni. Występują tu zatem dwa rzędy obliczeniowe. Ten rząd w którym obciążenie kulek jest wynikiem oddziaływania siły osiowej $Q$ i momentu wywrotnego $M$, nazywany jest rzędem nośnym, drugi rząd $\mathrm{w}$ którym obciążenie jest różnicą oddziaływań siły i momentu - rządem podtrzymującym. W pracy analizowano łożysko o następujących parametrach:

- średnica toczna $d_{t}=1400 \mathrm{~mm}$,

- średnica kulek $d=40 \mathrm{~mm}$,

- liczba kulek $z=84$,

- $\quad$ współczynnik przylegania kulki do bieżni $k_{p}=0,96$,

- nominalny kąt działania $\alpha_{0}=45^{\circ}$,

- twardość bieżni - 54 HRC,

- liczba śrub mocujących - 36 śrub M24-10.9 w każdym pierścieniu.

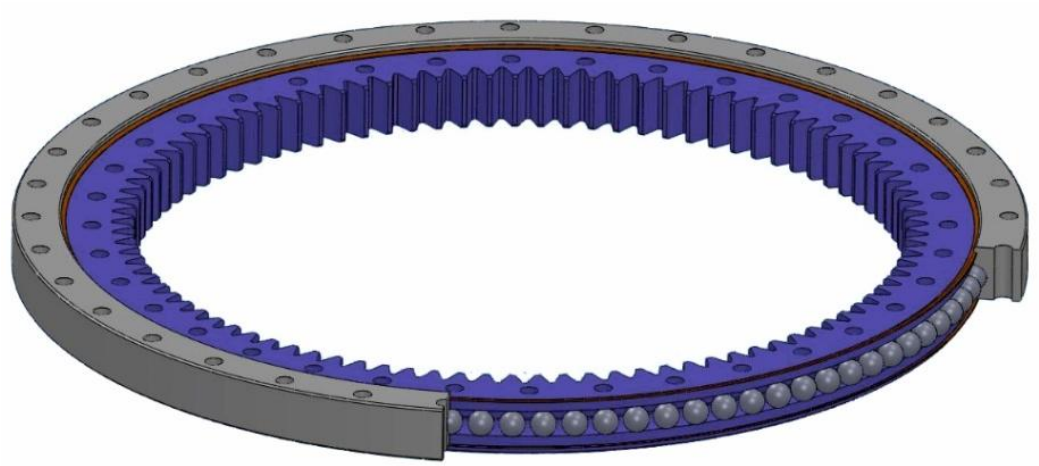

Rys. 2. Lożysko wieńcowe kulkowe jednorzędowe o styku czteropunktowym Źródto: opracowanie wtasne

Ponadto założono że:

- powierzchnie bieżni i części tocznych mają idealne kształty, 
a wszystkie części toczne maja tę samą średnicę,

- materiały pierścieni i części tocznych są jednorodne i izotropowe.

Przy obliczeniach łożysk tocznych wieńcowych istotne są dwa zagadnienia dotyczące bezpośrednio części tocznych:

- wyznaczenie maksymalnej siły jaką można obciążyć element toczny i związanego z nią maksymalnego odkształcenia części tocznej i bieżni,

- ustalenie charakteru zależności pomiędzy obciążeniem kulki a jej odkształceniem, a właściwie wzajemnym zbliżeniem bieżni łożyska.

Przyjęto, że granicznym obciążeniem kulki jest siła wywołująca względne odkształcenie plastyczne (MAZANEK E. 2005):

$$
\delta_{\text {pldop }}=2 \cdot 10^{-4} \text {. }
$$

Maksymalną siłę, jaką można obciążyć układ kulka - bieżnia obliczono z zależności:

$$
F_{\text {dop }}=\frac{9,9626 \cdot 10^{7} \mathrm{f}_{\mathrm{H}} \mathrm{d}^{2}}{\mathrm{c}_{\mathrm{p}}{ }^{2}}[\mathrm{~N}]
$$

gdzie: $\quad d[\mathrm{~mm}]-$ średnica kulki,

$c_{p}[\mathrm{MPa} 2 / 3]$ - stała nacisku w strefie styku punktowego,

$f_{H}$ - korekcyjny współczynnik twardości (MAZANEK E. 2005).

Odkształcenie kulki a tym samym zbliżenie bieżni łożyska określa zależność:

$$
\eta=\mathrm{cF}^{\mathrm{w}}
$$

gdzie:

$c$ - stała zależna od geometrii i materiałów stykających się elementów, $w$ - wykładnik potęgowy, w obliczeniach przyjęto $c=0,000122, w=2 / 3$ (MAZANEK E. 2005).

\section{Numeryczny model obliczeniowy}

Łożysko wieńcowe jest złożoną strukturą. Model obliczeniowy łożyska wykonano przy wykorzystaniu metody elementów skończonych 
(rys. 3). Przy budowie modelu można wyróżnić dwie grupy zagadnień: modelowanie łożyska $\mathrm{w}$ skali makro, tj. modelowanie pierścieni łożyska i ich zabudowy oraz modelowanie łożyska w skali lokalnej, czyli modelowanie zjawisk $\mathrm{w}$ strefie styku części tocznych z bieżniami łożyska (KANIA L., KRYNKE M. 2013). W łożysku wieńcowym występuje znaczna liczba stref styku (nierzadko kilkaset). Aby uniknąć niepożądanego zwiększenia rozmiarów modelu numerycznego, części toczne w łożysku zastępuje się tzw. superelementami wprowadzonymi m.in. w pracy (SMOLNICKI T. 2013). Głównym fragmentem superelementu jest element prętowy o nieliniowej charakterystyce, która jest określana na podstawie tzw. charakterystyki zastępczej strefy styku (KANIA L., KRYNKE M., MAZANEK E. 2012).

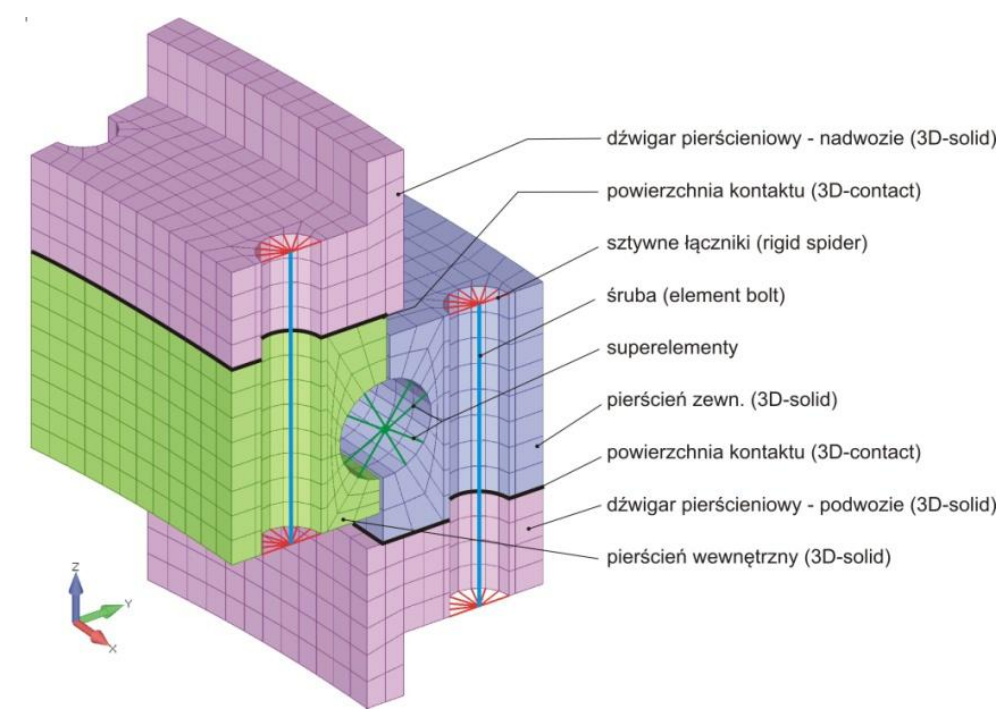

Rys. 3. Model MES sektora elementarnego tożyska kulkowego czteropunktowego

Źródto: opracowanie własne

Numeryczne modelowanie łożyska w skali makro sprowadza się do sporządzenia siatek modeli pierścieni łożyska, przyjęcia kształtu 
elementów zabudowy oraz przyjęcia sposobu modelowania śrub mocujących łożysko do zabudowy. Istotny jest sposób modelowania śrub. Można je modelować na kilka sposobów (MAZANEK E., KRYNKE M. 2010). W niniejszej pracy przyjęto, że śruby są modelowane za pomocą specjalnych elementów belkowych, którym można przypisać założone napięcie wstępne.

Do dyskretyzacji pierścieni łożyska a także do płyty i dźwigara pierścieniowego podwozia użyto 8-węzłowych elementów typu 3DSOLID. Dyskretyzacja podłużnic w podzespołach wsporczych została wykonana za pomocą elementów powłokowych typu SHELL. W modelach geometrycznych uwzględniono tylko najważniejsze elementy mające wpływ na sztywność ram nośnych. Ponadto przyjęto następujące uproszczenia:

- wszystkie ścianki i żebra postanowiono traktować jako powierzchnie,

- pominięto uzębienie pierścieni łożyska,

- pominięto drobne szczegóły konstrukcyjne, jak rowki pod uszczelki, otwory smarujące itp.

Jeden $\mathrm{z}$ dźwigarów zabudowy łożyska, który jest związany z podzespołem wsporczym, nazwano dźwigarem podparcia. Do drugiego dźwigara, nazwanego dźwigarem obciążenia, przykłada się obciążenie.

Pomiędzy odpowiednimi powierzchniami pierścieni łożyska a powierzchniami jego osadzenia zdefiniowano warunki kontaktu.

\section{Analiza uzyskanych wyników}

Obliczenia przeprowadzono dla wszystkich trzech modeli obliczeniowych oznaczonych jako V1, V2, V3. Celem prowadzonych obliczeń było określenie sił działających na poszczególne części toczne łożyska oraz śruby mocujące łożysko do struktur zabudowy. W niniejszym rozdziale skupiono się na analizie połączenia śrubowego, natomiast zakres obciążeń elementów tocznych był poruszony w pracy (KRYNKE M., BORKOWSKI S. 2014). W analizowanych typach 
konstrukcji wsporczych (V1, V2, V3) uwzględniono różne położenia nadwozia podczas jego obrotu. Wykorzystując symetrię badanych modeli analizy zostały przeprowadzone dla kąta $\theta=0 \div 90^{\circ}$. Obciążenie jakie przyjęto do obliczeń to siła osiowa $Q=200 \mathrm{kN}$, oraz moment wywrotny $M=2000 \mathrm{kNm}$. Jest to obciążenie graniczne wynikające $\mathrm{z}$ katalogowej charakterystyki nośności łożyska (ROTHER ERDE 2008).
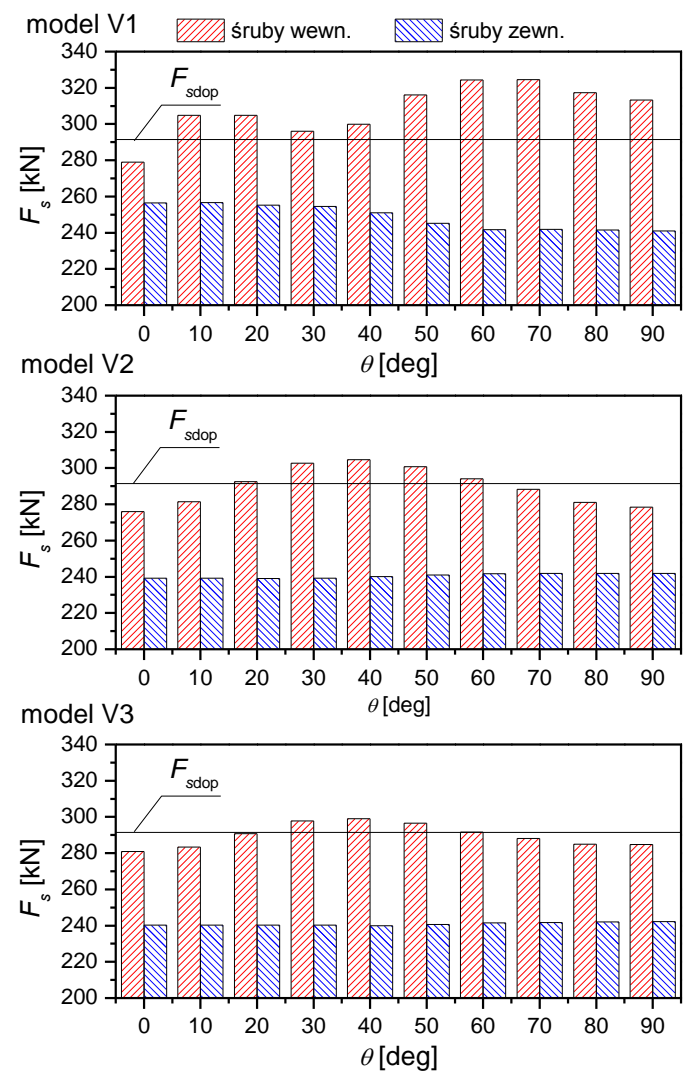

Rys. 4. Maksymalne obcią̇enia śrub dla różnych potożeń podzespotu wsporczego $\left(\theta=0 \div 90^{\circ}\right)$ dla modelu V1, V2 i V3

Źródto: opracowanie własne 
$\mathrm{Na}$ rysunku 4 przedstawiono maksymalne obciążenia śrub mocujących łożysko w funkcji położenia dźwigara obciążenia.

$\mathrm{Z}$ przedstawionych wyników widać, że w przypadku wszystkich typów analizowanych konstrukcji wsporczych zostało przekroczone graniczne obciążenie śrub (rys. 4), które w rezultacie może doprowadzić do uszkodzenia bieżni łożyska. $\mathrm{Z}$ przedstawionych rysunków można również zauważyć, że w przypadku modeli V2 oraz V3, największe obciążenia bieżni łożyska występują dla kąta położenia nadwozia wynoszącego około $40^{\circ}$.

$\mathrm{Na}$ wykresach zamieszczonym na rysunku 5 pokazano rozkład sił działających w poszczególnych śrubach mocujących łożysko dla wszystkich badanych modeli V1, V2, V3. Na pierwszym wykresie zamieszczono wyniki jakie otrzymano przy położeniu dźwigara obciążenia dla którego kąt $\theta=0^{\circ}$. Widoczne są wyraźnie skoki obciążenia na obwodzie łożyska. Te zjawiska są skutkiem deformacji pierścieni łożyska wywołanych deformacjami struktur podparcia i są przyczyną znacznego ograniczenia wytrzymałości połączenia śrubowego. $\mathrm{Na}$ pozostałych wykresach pokazano rozkłady obciążenia dla innych wybranych położeń dźwigara obciążenia. Charakter zjawisk jest podobny. Należy zwrócić uwagę, że badany rozkład obciążeń zależy od sztywności podzespołu wsporczego, przy czym najmniejsze różnice występują dla położenia $\theta=0^{\circ} \mathrm{tj}$. w sytuacji, kiedy oś obojętna działania momentu wywrotnego znajduję się w płaszczyźnie dla której sztywność ram nośnych jest największa. Jest to wyraźnie szczególne w przypadku podzespołu wsporczego V1, ponieważ jest to konstrukcja charakteryzująca się największym zróżnicowaniem sztywności po obwodzie siedziska pod łożyska. 

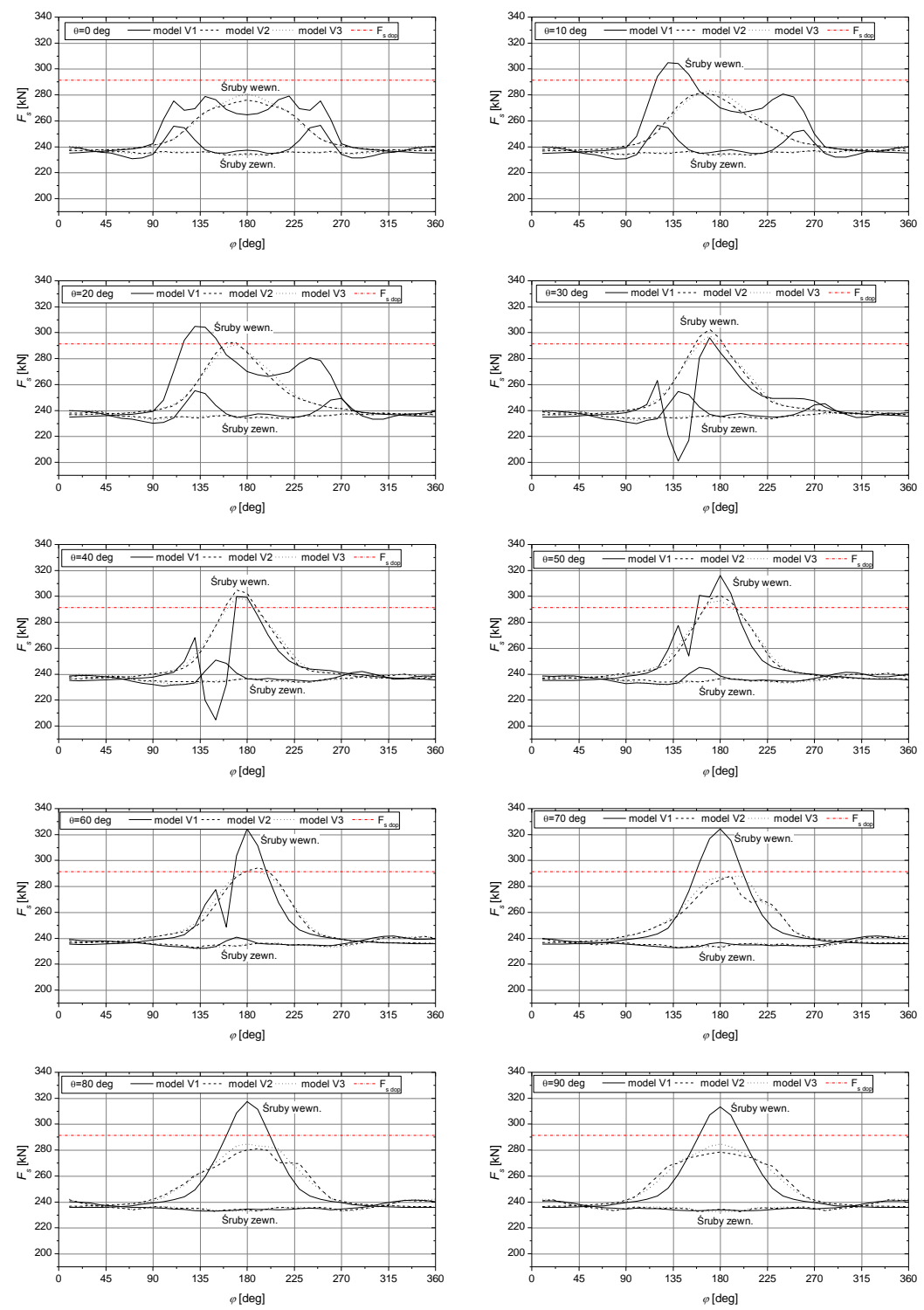

Rys. 5. Rozklad obciążenia na poszczególnych śrubach mocujących tożysko dla różnych położeń podzespołu wsporczego $\left(\theta=0 \div 90^{\circ}\right)$ 


\section{Źródto: opracowanie własne}

Badanie rozkładu obciążenia poszczególnych śrub w łożysku dla różnych położeń nadwozia względem podwozia maszyny roboczej pozwala ocenić jakość podzespołu wsporczego, a także wskazać newralgiczne punkty w konstrukcji mocowania łożysk do tych podwozi. Biorąc pod uwagę otrzymane wyniki dotyczące rozkładu obciążeń poszczególnych śrub mocujących łożysko, można stwierdzić, że wytrzymałość połączenia śrubowe jest niewystarczająca dla maszyny obciążonej przyjętymi siłami.

\section{Podsumowanie}

Przeprowadzone badania wskazują jak ważne przy konstruowaniu łożysk wieńcowych jest odpowiednie zaprojektowanie połączeń śrubowych. Wykazano, że $\mathrm{w}$ analizowanym połączeniu śrubowym zachodzą znaczne zmiany $\mathrm{w}$ zakresie obciążeń poszczególnych śrub łączących pierścienie łożyska wraz ze strukturami konstrukcji wsporczych. Jest to istotne ponieważ niejednokrotnie o nośności całego podzespołu decyduje wytrzymałość śrub. Wyniki z przytoczonych analiz świadczą o tym, że śruby w połączeniach pierścieni łożysk wieńcowych przenoszą nierównomierne obciążenia, zwłaszcza w przypadkach, gdy nie jest zachowana odpowiednia sztywność ustroju nośnego. Jeżeli zostaną przekroczone wartości dopuszczalne którejkolwiek ze śrub mocujących, to należy zmienić konstrukcję połączenia, tzn. dobrać śruby o większej średnicy lub wyższej klasie wytrzymałości, zwiększyć liczbę śrub lub też zmienić konstrukcję pierścieni (sztywność). Zerwanie chociaż jednej śruby $\mathrm{w}$ połączeniu szybko prowadzi do zerwania pozostałych, co kończy się poważną awarią całego urządzenia.

Nośność węzłów obrotowych w maszynie roboczej zależy nie tylko od nośności łożysk wieńcowych ale również od wytrzymałości połączenia śrubowego i sztywności podparcia łożyska. 
Przedstawiona analiza dowodzi słuszności stosowania metod numerycznych w praktycznych obliczeniach inżynierskich. Pozwala ona na dokładne określenie rozkładu sił przenoszonych przez poszczególne elementy łączące łożysko z siedziskami konstrukcji wsporczych. Takie modelowanie umożliwia szybką weryfikację wszystkich zmian konstrukcyjnych czy technologicznych wprowadzanych zarówno do geometrii łożyska jaki i do struktur jego zabudowy.

\section{LITERATURA}

1. DZIURSKi A., KANiA L., MAZANeK E. 2002. Obliczanie połaczeń śrubowych w tożyskach wieńcowych. Przegląd Mechaniczny nr 9, s. 30-36.

2. KANIA L., KRYNKE M. 2013. Computation of the general carrying capacity of slewing bearings. Engineering Computations Vol.30 nr 7. s.1011-1028.

3. Kania L., KrynKe M., MaZaneK E. 2012. A Catalogue Capacity of Slewing Bearings. Mechanism and Machine Theory Vol. 58. s. 29-45.

4. KANIA L., ŚPIEWAK S. 2014. Influence of radial forces on change of friction torque in twin slewing bearing. Machine Dynamics Research. Vol.38. s.121131.

5. KRYNKE M., BORKOWSKI S. 2014. Wptyw postaci konstrukcyjnej podzespotu wsporczego na dystrybucje obciażeń $w$ tożysku wieńcowym. Przegląd Mechaniczny, nr 7-8. s.23-29.

6. MAZANEK E. 2005. Zagadnienia konstrukcyjne i wytrzymatościowe w wielkogabarytowych tożyskach tocznych wieńcowych. Monografie $\mathrm{nr}$ 105, Wydawnictwo Politechniki Częstochowskiej, Częstochowa.

7. MAZANEK E., KRYNKE M. 2010. Możliwości modelowania śrub mocujacych tożysko wieńcowe. Transport przemystowy i maszyny robocze, 2(8), 53-57.

8. ROTHER ERDE - SLEWING BERING, Katalog 2008.

9. SMOLNICKI T. 2013. Wielkogabarytowe toczne węzty obrotowe. Zagadnienia globalne $i$ lokalne, Oficyna Wydawnicza Politechniki Wrocławskiej, Wrocław. 